\title{
Photodynamic inactivation effects on foodborne pathogens and its application in food products
}

\author{
D. L. Dong ${ }^{1}$, W. Q. Du ${ }^{1}$, X. Y. Wu ${ }^{1}$, S. L. Lin ${ }^{2}$, W. W. Riley ${ }^{3}$ and S. Z. Tang,* \\ ${ }^{1}$ Department of Food Science and Engineering, Jinan University, Guangzhou; \\ ${ }^{2}$ College of Food Science, Fujian Agriculture and Forestry University, Fuzhou; \\ ${ }^{3}$ International School, Jinan University, Guangzhou, China.
}

\begin{abstract}
Foodborne pathogens contaminating food products are considerable risk to food safety. Due to the negative effect of conventional thermal sterilization techniques on the nutritional and organoleptic characteristics of food, non-thermal photodynamic technology (PDT) has attracted considerable interest as a promising alternative. However, most studies on PDT have focused on its application limited in the field of clinical medicine. Therefore, further assessment of PDT efficacy against foodborne pathogens is indicated to better understand the true value of this methodology. Current knowledge of PDT as an alternative therapy in medical area is critically reviewed. Recent research on the effects of PDT on foodborne pathogens including bacteria, fungi, virus and parasites and application of PDT in food processing are discussed in detail, with focus on potential application in the safety of fruits and vegetables, meats and meat products, aquatic products and dairy products. PDT has focused on most foodborne pathogenic bacteria and showed favourable inactivation effect, but relatively scarce research has been conducted on foodborne fungi, viruses and parasites. When PDT was used on foodstuff, no detrimental changes in the nutritional and organoleptic profiles have been reported. However, PDT effect may be weakened by food irregular geometries, complex surface structures,
\end{abstract}

\footnotetext{
*Corresponding author: tangsz@jnu.edu.cn
}

microbial ecology, antioxidant components and food matrices. Further study on industrial application of PDT in pathogenic bacteria disinfection and mechanisms of PDT inactivation of viruses and parasites should be carried out.

KEYWORDS: photodynamic technology (PDT), foodborne pathogens, food stuff.

\section{Introduction}

Food supplies individuals with the essential nutrients needed to support daily basal and voluntary activities. However, food is also one of the most common transmission routes for pathogens. A number of large-scale food safety incidents have resulted from the consumption of food contaminated by pathogens [1-5]. Rapid economic development, with its attendant competitive pressures, and lax regulatory standards and enforcement has given rise to a higher risk of exposure to foodborne pathogens. Foodborne diseases caused by etiological agents have been of even greater concern.

The WHO (2015) [6] estimated that 600 million people fell ill, 420,000 people died and 33 million people experienced ill health annually due to consumption of contaminated food. According to another report by the World Bank [7], low- to middle-income countries lose on average US $\$ 110$ billion annually on medical expenses and productivity. While the food supply in the United States of America is among the safest in the world [8], an estimated 9.4 million foodborne illness, 
55,961 hospitalizations and 1,351 deaths are caused by 31 different pathogens each year [9]. Foodborne pathogens contribute to a considerable public health and economic burden worldwide, indicating that food safety deserves more support in the form of resources and advanced technologies.

Thermal treatments are the most common strategies used to inactivate foodborne pathogens as they are safe and easy to operate [10]. However, these processes damage a number of dietary nutrients and can alter the taste of food. Therefore, it is preferable that non-thermal techniques be further developed and utilized. In recent years, the shortcomings of some nonthermal techniques have been exposed and reviewed. Chlorine-based treatment, for example, produces toxic residues, while high pressure processing is costly, the safety of irradiation is controversial, and ultrasound may negatively affect the organoleptic properties of food [11]. Therefore, novel alternative non-thermal technologies are urgently needed to address these considerations.

Photodynamic technology (PDT), which involves the interaction of photosensitizers (PSs), light and oxygen, was first used in clinical medicine to remove lesions while avoiding damage to normal tissues. Later, this technology was applied to the treatment of microbial infections and showed its possibility in the field of food safety [12]. Although, several studies on photodynamic inactivation on foodborne pathogens have been published, the results have been equivocal. Hence, the aim of this review is to provide a comprehensive information on PDT, its impact on foodborne pathogens, and its application to specific food products.

\section{History and mechanism}

PDT is regarded as an innovate technology to modern food production, but its history can be traced back more than four thousand years. In ancient India, Egypt and China, some physicians and herbalists discovered herbal extracts that were photosensitive to sunlight and effective in treating skin diseases [13, 14]. In 1900, Oscar Raab accidentally discovered the "photodynamic phenomenon". When acridine red dye was exposed to sunlight, death of the single-celled aquatic protists Paramecia was observed. Based on this "photodynamic phenomenon", Raab's tutor, Herman von Tappeiner, and a dermatologist, Albert Jesionek, combined the red fluorescent dye eosin with sunlight to clinically treat skin carcinomas. Subsequently, the term "photodynamic effect" was coined by von Tappeiner and Jesionek to describe the photosensitization reaction generated by the combined effect of PSs, visible light and oxygen [13-15]. In 1931, Kautsky and de Bruijn put forward the concept that the energy of PS in the excited state can transfer to oxygen and generate the production of singlet oxygen $\left({ }^{1} \mathrm{O}_{2}\right)$, which is regarded as essential in producing cytotoxicity [14]. Then a great effort was made to explore the mechanism behind PDT.

It is generally accepted that photodynamic reaction needs three key determinants - PS, light and oxygen. As shown in Figure 1, activated by a light source at the proper wavelength, PSs that selectively gather in target tissues or cells will transfer from the ground state to the excited state and generate reactive oxygen species (ROS) through type I and type II processes. ROS can elicit phototoxic effects on adjacent biomolecules (proteins, lipids, nucleic acids), thereby resulting in microbial or malignant cell death [16]. It has been proposed that type I reactions play a more important role in damaging pathogens while type II reactions contribute more to malignant cell death [12]. However, a majority of scientists support the idea that a contribution of the two reactions depends on many factors, such as PSs, targets and their interactions [17].

\section{Photodynamic technology in medicine}

At an early stage, PDT was mainly focused on the treatment of tumours in medical settings. Photosensitizer photofrin represented the first approved PDT for the prophylactic treatment of bladder cancer in Canada in 1993, and it was subsequently granted approval for the treatment of other cancers in several European countries, Japan and in the United States [18]. After, photogem, photosan, hemporfin and additional PSs have since been approved for PDT treatment in other countries [19].

According to Ding [20], PDT is regarded as the fourth therapy of choice, after surgery, chemotherapy 


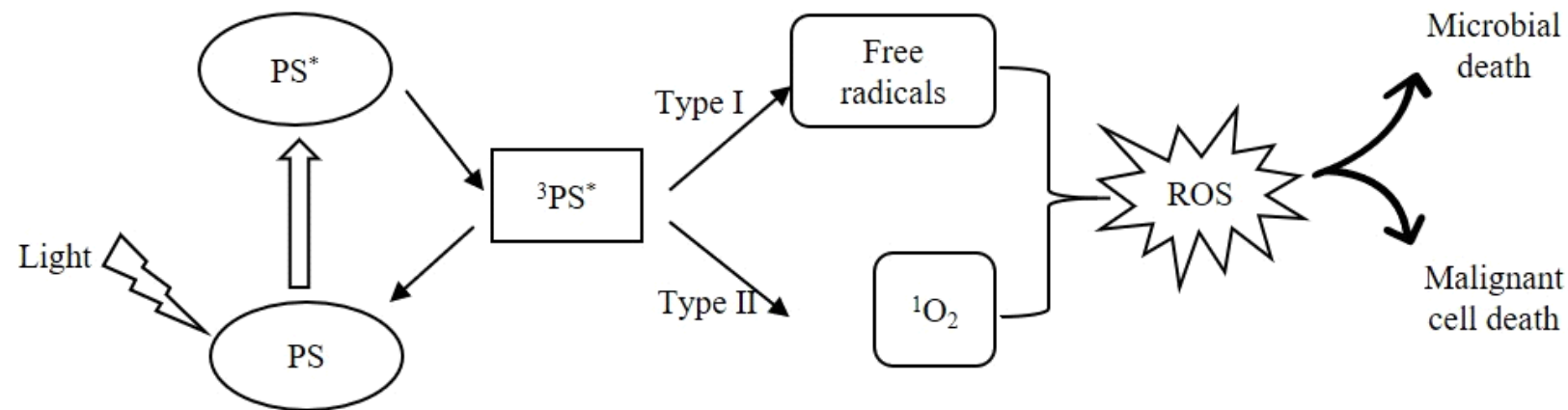

Figure 1. Scheme of PDT mechanism. PS: PS in its ground state, PS* PS in its excited state, ${ }^{3} \mathrm{PS}^{*}$ : PS in its triplet state, ${ }^{1} \mathrm{O}_{2}$ : singlet oxygen.

and radiotherapy. It is a promising treatment for malignant and non-malignant tumours. In addition, by virtue of the fluorescence of PSs, PDT is used to accurately diagnose tumours and precancerous lesions, which contribute to a high probability of success when conducting surgical resections and real-time monitoring.

PDT is also used to treat viral and bacterial infections, yet this technology has received little attention since its discovery in the middle of the last century, and especially since the advent of antibiotic therapy. But now that antibiotic resistance has emerged as a critical issue in the medical community, PDT is again looked at a viable alternative method in the elimination of pathogenic bacteria [21]. Antibacterial photodynamic therapy was first applied for the treatment of herpes infections in the early 1970s [22]. Consequently, PDT was successfully applied to wound infections, psoriasis, helicobacter infections, acne vulgaris and the disinfection of blood products [22].

\section{Effects of photodynamic technology on foodborne pathogens}

The food industry is frequently troubled by a variety of foodborne pathogens. As one of several means to address these food safety issues, progress has been made in the advancement of this technology since the early $21^{\text {st }}$ century.

\subsection{Photodynamic inactivation of foodborne bacteria}

Research on photodynamic inactivation of foodborne bacteria has come from different groups [23-30].
Luksienè et al. (2009) [31], in a review, introduced PDT and promoted its application to the critical area of food safety. Numerous followup attempts were made to investigate responses of a broad spectrum of bacteria to PDT treatment. The majority of these studies used PDT against common gram-positive and gram-negative foodborne bacteria (Table 1), including Listeria monocytogenes, Staphylococcus aureus, Bacillus cereus, Escherichia coli and Salmonella spp. To improve PDT, several main factors - microorganisms, PSs, light sources and incubation time - will be evaluated.

\subsubsection{Targeted bacteria}

Notably, different inactivation effects following PDT treatment vary from species to species and even from strain to strain [32]. Ren et al. (2008) [29] observed that compared with B. cereus, less E. coli population was inactivated by PDT. It revealed that compared to gram-positive bacteria, gram-negative microbes were less susceptible to PDT treatment. A similar conclusion was reached from photodynamic inactivation of L. monocytogenes and S. enterica [32, 33] and PDT treatment against $S$. typhimurium and $S$. aureus $[34,35]$. Such a significant difference is caused by the variation in cell membrane surfaces between gram-positive and gram-negative bacteria. The simpler structure of gram-positive bacteria permits PSs to penetrate cells readily and generate ROS, with greater impact on inner cell components. For gram-negative bacteria, however, the presence of outer membrane containing lipopolysaccharides and phospholipids results in decreased permeability. 
Table 1. Studies on PDT against foodborne bacteria.

\begin{tabular}{|c|c|c|c|c|}
\hline Bacteria & PS & Light source & Reduction & Reference \\
\hline \multirow{3}{*}{$\begin{array}{l}\text { Listeria } \\
\text { monocytogenes }\end{array}$} & $\begin{array}{l}\text { methylene blue } \\
(0.5 \mu \mathrm{g} / \mathrm{mL})\end{array}$ & $\begin{array}{l}\text { tungsten-halogen lamp } \\
\left(200 \mathrm{~mW} / \mathrm{cm}^{2}, 10 \mathrm{~min}\right)\end{array}$ & $7 \log$ & {$[92]$} \\
\hline & $\begin{array}{l}\text { hematoporyrin } \\
\text { monomethyl ether } \\
(25 \mu \mathrm{g} / \mathrm{mL})\end{array}$ & $\begin{array}{l}\text { bromine-tungsten lamp } \\
\left(200 \mathrm{~mW} / \mathrm{cm}^{2}, 30 \mathrm{~min}\right)\end{array}$ & $\begin{array}{c}>7 \log \\
99.9999 \%\end{array}$ & [93] \\
\hline & $\begin{array}{c}\text { 5-aminolevulinic acid } \\
(7.5 \mathrm{mM})\end{array}$ & $\begin{array}{c}\text { LED }\left(400 \mathrm{~nm}, 20 \mathrm{~mW} / \mathrm{cm}^{2},\right. \\
20 \mathrm{~min})\end{array}$ & $4 \log$ & {$[60]$} \\
\hline \multirow{2}{*}{$\begin{array}{l}\text { Staphylococcus } \\
\text { aureus }\end{array}$} & $\operatorname{eosin} Y(5 \mu \mathrm{mol} / \mathrm{L})$ & $\begin{array}{l}\text { LED }(490-570 \mathrm{~nm}, \\
\left.38.2 \mathrm{~J} / \mathrm{cm}^{2}\right)\end{array}$ & $\begin{array}{l}>6 \log , \\
99.9999 \%\end{array}$ & [94] \\
\hline & curcumin $(75 \mu \mathrm{M})$ & $\operatorname{LED}\left(470 \mathrm{~nm}, 417 \mathrm{~J} / \mathrm{cm}^{2}\right)$ & $\begin{array}{l}\sim 6 \log , \\
99.9999 \%\end{array}$ & [95] \\
\hline \multirow{3}{*}{ Bacillus cereus } & $\begin{array}{l}5 \text {-aminolevulinic } \\
\operatorname{acid}(7.5 \mathrm{mmol} / \mathrm{L})\end{array}$ & $\operatorname{LED}\left(400 \mathrm{~nm}, 24 \mathrm{~J} / \mathrm{cm}^{2}\right)$ & $6.3 \log$ & [24] \\
\hline & $\begin{array}{l}\text { Na-chlorophyllin } \\
\left(7.5 \times 10^{-7} \mathrm{~mol} / \mathrm{L}\right)\end{array}$ & $\begin{array}{c}\text { LED }\left(405 \mathrm{~nm}, 20 \mathrm{~mW} / \mathrm{cm}^{2},\right. \\
5 \mathrm{~min})\end{array}$ & $7 \log$ & {$[96]$} \\
\hline & $\begin{array}{c}\operatorname{eosin} Y \\
(7.5 \mu \mathrm{mol} / \mathrm{L})\end{array}$ & $\begin{array}{l}\text { LED }(490-570 \mathrm{~nm}, \\
\left.140.2 \mathrm{~J} / \mathrm{cm}^{2}\right)\end{array}$ & $>3 \log$ & [94] \\
\hline \multirow{5}{*}{$\begin{array}{c}\text { Vibrio } \\
\text { parahaemolyticus }\end{array}$} & $\begin{array}{l}\text { methylene blue } \\
(0.05 \mathrm{mg} / \mathrm{mL})\end{array}$ & $\begin{array}{c}\text { xenon lamp }\left(200 \mathrm{~mW} / \mathrm{cm}^{2},\right. \\
25 \mathrm{~min})\end{array}$ & $5 \log$ & [97] \\
\hline & $\begin{array}{l}\text { methylene blue } \\
\qquad(10 \mathrm{mg} / \mathrm{L})\end{array}$ & $\begin{array}{l}\text { bromine-tungsten lamp } \\
\quad(350 \sim 2501 \mathrm{~nm}, \\
\left.200 \mathrm{~mW} / \mathrm{cm}^{2}, 30 \mathrm{~min}\right)\end{array}$ & $\begin{array}{l}>7 \log \\
99.9999 \%\end{array}$ & [98] \\
\hline & $\begin{array}{l}\text { chlorophyllin } \\
\left(1.5 \times 10^{-5} \mathrm{M}\right)\end{array}$ & $\operatorname{LED}\left(405 \mathrm{~nm}, 30 \mathrm{~J} / \mathrm{cm}^{2}\right)$ & $95 \%$ & [64] \\
\hline & $\operatorname{eosin} \mathrm{Y}(10 \mu \mathrm{mol} / \mathrm{L})$ & $\begin{array}{c}\operatorname{LED}(530 \pm 40 \mathrm{~nm} \\
\left.9.0 \mathrm{~J} / \mathrm{cm}^{2}\right)\end{array}$ & $0.8 \log$ & [94] \\
\hline & curcumin $(75 \mu \mathrm{M})$ & $\operatorname{LED}\left(470 \mathrm{~nm}, 417 \mathrm{~J} / \mathrm{cm}^{2}\right)$ & $\begin{array}{l}\sim 6 \log , \\
99.9999 \%\end{array}$ & {$[95]$} \\
\hline Cronobacter sakazakii & $\begin{array}{l}\text { methylene blue } \\
(100 \mathrm{mg} / \mathrm{L})\end{array}$ & laser $\left(532 \mathrm{~nm}, 417 \mathrm{~J} / \mathrm{cm}^{2}\right)$ & $99.3 \%$ & [99] \\
\hline \multirow[t]{2}{*}{ Salmonella enterica } & $\operatorname{eosin} \mathrm{Y}(10 \mu \mathrm{mol} / \mathrm{L})$ & $\begin{array}{l}\text { LED }(490-570 \mathrm{~nm}, \\
\left.159.3 \mathrm{~J} / \mathrm{cm}^{2}\right)\end{array}$ & $1.7 \log$ & [94] \\
\hline & curcumin $(75 \mu \mathrm{M})$ & $\operatorname{LED}\left(470 \mathrm{~nm}, 417 \mathrm{~J} / \mathrm{cm}^{2}\right)$ & $2.82 \log$ & [95] \\
\hline \multirow{2}{*}{$\begin{array}{l}\text { Pseudomonas } \\
\text { aeruginosa }\end{array}$} & $\operatorname{eosin} \mathrm{Y}(10 \mu \mathrm{mol} / \mathrm{L})$ & $\begin{array}{l}\operatorname{LED}(490-570 \mathrm{~nm}, \\
\left.\quad 106.2 \mathrm{~J} / \mathrm{cm}^{2}\right)\end{array}$ & $99.9999 \%$ & [94] \\
\hline & curcumin $(75 \mu \mathrm{M})$ & $\operatorname{LED}\left(470 \mathrm{~nm}, 417 \mathrm{~J} / \mathrm{cm}^{2}\right)$ & $0.33 \log$ & [95] \\
\hline
\end{tabular}

As a result, insufficient PSs are absorbed into the gram-negative bacteria cells, and cytotoxicity is less efficient $[36,37]$. Thus, inactivation of gramnegative bacteria has become an important issue.
To enhance photoinactivation of gram-negative bacteria, the use of positively charged (cationic) photosensitizers, encapsulated water-soluble photosensitizers, addition of inorganic salts, 
photocatalysts, and other methods have been proposed.

Buchovec et al. (2016) [38] immobilized PS chlorophyllin (Chl) into a positively charged chitosan polymer and treated S. enterica. Then a 7 $\log$ reduction in viability was observed, while just a $1.8 \log$ reduction was obtained by Chl alone. Chl as a negatively-charged PS cannot traverse the intricate negatively charged cell wall of Salmonella. The positively charged chitosan polymer can contribute to a reduction of bacteria cells by itself and it is able to reinforce interaction with the cell wall; therefore, Chl can easily enter the cell and elicit synergic effects.

Winter et al. (2013) [39] adopted a pre-treatment with $\mathrm{CaCl}_{2}$ for cell wall permeabilization, which differs from chitosan and has a negligible impact on cell viability. Then they employed curcumin bound to polyvinylpyrrolidone (PVP-C) as a water-soluble photosensitizer to decrease the E. coli cell count by more than $3 \log$ units, which exceeds the criterion of the American Society of Microbiology standard. The enhancement of photodynamic activity with potassium iodide was also reported by Santos et al. [34] Eosin Ymediated PDT demonstrated an almost $4 \log$ reduction in cell count for $S$. aureus and a $2 \log$ reduction for S. typhimurium, while $100 \mathrm{mM} \mathrm{KI}$ addition led to a total reduction of both Salmonella species. The KI treatment greatly lowered the requirement of PS concentration and light dose. Hence, changing the hydrophobicity of PS or pre-treatment with potassium iodide could be helpful in improving PDT efficacy.

Aponiene et al. (2015) [40] suggested using photocatalyst to enhance the antimicrobial effect of PDT. Interestingly, when Chl was combined with photocatalyst zinc oxide nanoparticles $(\mathrm{ZnO}$ $\mathrm{NPs}$ ) to treat $E$. coli cells, the incubation sequence significantly influenced the PDT effects. They found that $\mathrm{ZnO} \mathrm{NPs}$ and $\mathrm{Chl}$ were competitive at binding sites on cell surfaces. The addition of $\mathrm{Chl}$ first hindered the effective interaction of bacteria with $\mathrm{ZnO} \mathrm{NPs}$, while added $\mathrm{ZnO}$ NPs first inhibited binding to negatively charged cell surfaces but then enhanced the binding to negatively charged $\mathrm{Chl}$ molecules. This finding provides support for the use of photocatalysts in
PDT, but further clarification is pending. Still to be determined is whether the incubation sequence has the same influence on other combinations of PSs and photocatalysts and if incubation time of the photocatalysts will lead to different PDT effects.

It is noteworthy that a broad spectrum of bacteria is able to naturally produce endogenous PSs, such as intracellular porphyrin compounds. Most of these can be excited using a 405-460 nm light source in the blue region of the spectrum [41]. In this respect, Kim et al. $(2015,2017)$ [41-43] and Kumar et al. (2015, 2017) [44, 45] conducted a series of experiments to investigate blue LEDbased photosensitization on bacteria. From these studies, it was found that without the addition of exogenous PS, a higher light dose in the form of an increased illumination time was required, and this method may be more suitable for food preservation. It has potential application to household refrigerators, fruit display showcases, and storage rooms with dual functions as a light source and in the control of microorganisms [41].

\subsubsection{Biofilms}

Under suitable conditions, there is a high probability that microbes can exist as biofilms, which are resistant to anti-microbial agents, due to the presence of the exopolysaccharide (EPS) matrix. Differing from planktonic bacteria, biofilms are sessile cells that are able to adhere to a variety of surfaces or to each other. Therefore, eradicating biofilms during food processing is necessary to avoid contamination of the final food product $[46,47]$. PDT, as a novel but "intelligent" technology, has exhibited good results in eliminating biofilms, based on in vitro research (Table 2).

Biofilms at the early stage of growth are most susceptible [48], but the resistance to PDT can increase by a factor of 10-100 when biofilms are formed. Therefore a higher photosensitization dose (light and PS dose) is required to inactivate the biofilms compared with the dose needed to inactivate planktonic cells [49]. Ma (2017) [50] did not obtain a satisfactory anti-biofilm effect on B. cereus by rose bengal (RB)-based PDT. It was speculated that the complex structure of biofilms may affect the absorption of PSs and the 
Table 2. Studies on PDT against bacterial biofilms.

\begin{tabular}{|c|c|c|c|c|}
\hline Biofilms & PS & Light source & Reduction & Reference \\
\hline \multirow{4}{*}{$\begin{array}{l}\text { Staphylococcus } \\
\text { aureus }\end{array}$} & erythrosine $(7.5 \mu \mathrm{mol} / \mathrm{L})$ & green LED $\left(295.83 \mathrm{~J} / \mathrm{cm}^{2}\right)$ & $\begin{array}{c}>6.5 \log \\
100 \%\end{array}$ & \multirow{2}{*}[100]{} \\
\hline & rose bengal $(1 \mu \mathrm{mol} / \mathrm{L})$ & green LED $\left(49.59 \mathrm{~J} / \mathrm{cm}^{2}\right)$ & $\begin{array}{c}>6.5 \log \\
100 \%\end{array}$ & \\
\hline & rose bengal $(250 \mu \mathrm{mol} / \mathrm{L})$ & $\begin{array}{l}\operatorname{LED}(530 \pm 40 \mathrm{~nm} \text {, } \\
\left.10 \mathrm{~mW} / \mathrm{cm}^{2}, 30 \mathrm{~min}\right)\end{array}$ & $\begin{array}{c}7.63 \log \\
100 \%\end{array}$ & [34] \\
\hline & $\begin{array}{l}\text { Erythrosine } \\
(500 \mu \mathrm{mol} / \mathrm{L})\end{array}$ & $\begin{array}{l}\operatorname{LED}(530 \pm 40 \mathrm{~nm}, \\
\left.10 \mathrm{~mW} / \mathrm{cm}^{2}, 30 \mathrm{~min}\right)\end{array}$ & $\begin{array}{c}7.63 \log , \\
100 \%\end{array}$ & \multirow{3}{*}[100]{} \\
\hline \multirow{2}{*}{$\begin{array}{l}\text { Salmonella } \\
\text { typhimurium }\end{array}$} & rose bengal $(500 \mu \mathrm{mol} / \mathrm{L})$ & $\begin{array}{l}\text { LED }(530 \pm 40 \mathrm{~nm}, \\
\left.10 \mathrm{~mW} / \mathrm{cm}^{2}, 30 \mathrm{~min}\right)\end{array}$ & $>3 \log$ & \\
\hline & erythrosine $(250 \mu \mathrm{mol} / \mathrm{L})$ & $\begin{array}{l}\operatorname{LED}(530 \pm 40 \mathrm{~nm}, \\
\left.10 \mathrm{~mW} / \mathrm{cm}^{2}, 30 \mathrm{~min}\right)\end{array}$ & $<1 \log$ & \\
\hline \multirow{5}{*}{$\begin{array}{c}\text { Listeria } \\
\text { monocytogenes }\end{array}$} & $\begin{array}{l}\text { 5-aminolevulinic acid } \\
(10 \mathrm{mM})\end{array}$ & $\operatorname{LED}\left(400 \mathrm{~nm}, 18 \mathrm{~J} / \mathrm{cm}^{2}\right)$ & $3.1 \log$ & \multirow{3}{*}[60]{} \\
\hline & $\begin{array}{c}\text { rose bengal } \\
(0.25 \mu \mathrm{mol} / \mathrm{L})\end{array}$ & green LED $\left(12.99 \mathrm{~J} / \mathrm{cm}^{2}\right)$ & $\begin{array}{l}>5 \log \\
100 \%\end{array}$ & \\
\hline & erythrosine $(1 \mu \mathrm{mol} / \mathrm{L})$ & green LED $\left(61.56 \mathrm{~J} / \mathrm{cm}^{2}\right)$ & $\begin{array}{l}>5 \log \\
100 \%\end{array}$ & \\
\hline & curcumin $(3.7 \mathrm{mg} / \mathrm{L})$ & $\begin{array}{l}\text { blue LED }(400-500 \mathrm{~nm}, \\
\left.270 \mathrm{~J} / \mathrm{cm}^{2}\right)\end{array}$ & $4.9 \log$ & \multirow{2}{*}{ [94] } \\
\hline & $\begin{array}{l}\text { Tetra }-\mathrm{Py}^{+}-\mathrm{Me} \\
(11.9 \mathrm{mg} / \mathrm{L})\end{array}$ & $\begin{array}{l}\text { white LED }(400-700 \mathrm{~nm} \text {, } \\
\left.270 \mathrm{~J} / \mathrm{cm}^{2}\right)\end{array}$ & $1.1 \log$ & \\
\hline \multirow{2}{*}{ Escherichia coli } & rose bengal $(9 \mu \mathrm{mol} / \mathrm{L})$ & green LED $\left(486.4 \mathrm{~J} / \mathrm{cm}^{2}\right)$ & $\begin{array}{l}>5 \log \\
100 \%\end{array}$ & \multirow{4}{*}[100]{} \\
\hline & erythrosine $(50 \mu \mathrm{mol} / \mathrm{L})$ & green LED $\left(291.08 \mathrm{~J} / \mathrm{cm}^{2}\right)$ & $\begin{array}{l}>5 \log \\
100 \%\end{array}$ & \\
\hline \multirow{2}{*}{$\begin{array}{l}\text { Enterococcus } \\
\quad \text { hirae }\end{array}$} & $\begin{array}{c}\text { rose bengal } \\
(0.75 \mu \mathrm{mol} / \mathrm{L}) \\
\end{array}$ & green LED $\left(38 \mathrm{~J} / \mathrm{cm}^{2}\right)$ & $6 \log , 100 \%$ & \\
\hline & $\begin{array}{c}\text { rose bengal } \\
(0.75 \mu \mathrm{mol} / \mathrm{L})\end{array}$ & green LED $\left(38 \mathrm{~J} / \mathrm{cm}^{2}\right)$ & $6 \log , 100 \%$ & \\
\hline Bacillus cereus & rose bengal $(50 \mu \mathrm{M})$ & Laser $\left(532 \mathrm{~nm}, 100 \mathrm{~J} / \mathrm{cm}^{2}\right)$ & $1.38 \log$ & {$[50]$} \\
\hline
\end{tabular}

polysaccharide structure may obstruct the diffusion of ROS.

As mentioned above, bacteria in the planktonic form are more susceptible to PDT treatment induced by cationic PSs. However, Bonifácio et al. (2018) [51] observed that curcumin showed a greater photodynamic inactivation effect on the L. innocua biofilms than the effect of the cationic tetra-cationic porphyrin, Tetra-Py ${ }^{+}-\mathrm{Me}$. The authors suggested that biofilm reductions are determined primarily by the mechanism involved in antibiofilm activity. Curcumin mainly generates singlet oxygen through a type II reaction, while Tetra-Py ${ }^{+}-\mathrm{Me}$ in aqueous medium more easily produces free radicals through a type I reaction. Because of the abundance of singlet-oxygen quenchers in the extracellular matrix of biofilms, PDT based on PSs undergoes a type II mechanism and thus does not work efficiently. It was 
hypothesised that selecting a PS that stimulates a type I PDT mechanism would improve antibiofilm performance.

In addition, rupture of the EPS is a more immediate approach to enhancing PDT effects against biofilms. D-tyrosine has been confirmed to have the ability to reduce the formation of extracellular polymeric substances but not to negatively impact the growth of internalised bacteria. $\mathrm{Wu}$ (2016) [49] added D-tyrosine to weaken the protection of EPS and to intensify the photoinactivation effects of PDT. Consequently, Vibrio parahaemolyticus biofilms were efficiently inactivated by methylene blue-mediated PDT. Aided by chitosan, toluidine blue O (TBO)-based PDT showed improved performance of Cronobacter sakazakii biofilms inactivation as well [52]. Other strategies that have been illustrated elaborately by Pinto et al. [53] in disassembling the EPS matrix can also be considered as assistance to PDT treatment.

\subsubsection{Photosensitizers}

During the initial application of PDT for the inactivation of foodborne pathogens, PSs like hematoporphyrin methyl ether (HMME), methylene blue (MB), TBO were "borrowed" from photodynamic therapy while food additives now are accepted. Numerous studies have shown that photodynamic inactivation effects are PS dosedependent. Within the proper range, higher bactericidal rate can be obtained by increasing the PS concentration. No significant photodynamic damage will be produced below the threshold dose [54], whereas excessive PS may block PDT activity [32, 50, 55]. This blocking phenomenon has been termed "self-shielding"- excess PSs in solution impeding light penetration and making insufficient PDT effects occur due to the presence of unexcited PSs [54, 56].

The charge on the PS is also of great importance to the PDT effect. Other PS properties, the size, the triplet quantum yield, the inclination for type I or type II mechanisms, molecular asymmetry and amphiphilicity are all of concern in the design of an ideal PS [57].

\subsubsection{Light source}

Tissue penetration is an important consideration in clinical treatment, as longer wavelength implies deeper penetration. Light sources of 400-500 nm, however, are more frequently employed to inactivate foodborne pathogens, which can penetrate to $\sim 300-400 \mu \mathrm{m}$ below the surface of the tissue. Conventional light sources like incandescent and halogen lamps were primarily selected for use, followed by metal halide lamp, short-arc xenon lamp, ultraviolet lamp, laser and LED equipment [31]. Among these, LED equipment is more appealing due to its properties relative to conventional lamps and lasers.

Light dose is one of the most vital factors in the use of PDT. It is calculated by multiplying the power density by the illumination time. To improve the photodynamic inactivation effects by increasing the light dose, operators either used more powerful light sources, or they extended the exposure time. These two approaches should be chosen based on actual processing requirements.

\subsubsection{Incubation time}

Due to the extremely short life-time of ${ }^{1} \mathrm{O}_{2}$, PSs should be strictly located in or nearby targeted cells to guarantee efficient and exact photodynamic inactivation activity. In theory, longer incubation before irradiation will enable sufficient attachment of PSs to their targets and generate a better photodynamic inactivation effect. In consistent with the rule, major experiments revealed the fact that prolonging incubation time did not produce a remarkable fluctuation of the inactivation rate, even when increasing the incubation time from 30 to $90 \mathrm{~min}[32,58,59]$. Nevertheless, some studies have demonstrated that the incubation period plays a crucial role in 5-aminolevulinic acid (ALA)-based PDT. As a precursor, ALA can trigger the production of endogenous photosensitizers (protoporphyrin IX [PpIX), uroporphyrin and coproporphyrin). Since time is needed for ALA to convert to an endogenous photosensitizer, the adequate incubation time is necessary for PDT mediated by ALA [23, 24, 60].

\subsection{Effects of photodynamic technology on other foodborne pathogens}

To date, PDT research has concentrated largely on the inactivation of foodborne bacteria. In reality, the food industry also faces the risk of contamination by foodborne fungi, viruses and parasites. Therefore, photodynamic inactivation 
effects on these pathogens have also attracted considerable attention.

\subsubsection{Fungi}

Earlier studies on the effects of photodynamic inactivation on foodborne pathogen were limited to bacteria and fungi. Fungi contamination is a troublesome issue during food processing, and it has been shown that numerous species of yeast and micromycetes can be inactivated or inhibited by PDT treatment [61-64]. Many scientists believe that photoinactivation of fungi is realized by ROS perforation of the cell wall followed by the translocation of PSs into the cell and the consequent induction of lethal damage to crucial cell components [65-67].

Moreover, data suggests that PDT treatment has an inactivation effect on fungal spores [58, 68]. By fluorescent microscopy, PS uptake of spores was observed by Li et al. [58]. It was shown that PS may transit the cell membrane, resulting in its accumulation within the cell.

\subsubsection{Viruses}

Clinically, PDT has been widely adopted for the inactivation of viruses in disease treatment protocols and to decontaminate blood products. However, literature on the effect of PDT on foodborne viruses is scant. Randazzo et al. (2016) [69] examined PDT effect on human norovirus (HuNOV) surrogates, feline calicivirus (FCV) and murine norovirus (MNV). This treatment reduced FCV titer by $5 \log \mathrm{TCID}_{50} / \mathrm{mL}$ and MNV titer by $0.73 \log \mathrm{TCID}_{50} / \mathrm{mL}$. Since MNV is more acceptable as a surrogate of HuNOV, the PDT employed by Randazzo did not obtain satisfactory result. $\mathrm{Wu}$ (2015) [70], however, found a detectable decrease in MNVs within 1-minute illumination, which was in contrast to the result of Randazzo et al. [69] Furthermore, the data of Wu [70] were used to describe a mechanism behind the photoinactivation of norovirus, which could explain how the cell ultrastructure, the integrity of viral nucleic acid and the stability of viral capsid proteins were altered.

It has been suggested in several medical reviews that enveloped viruses are more vulnerable to PDT treatment $[22,71]$. However, no method has been reported to enhance PDT effects on unenveloped viruses. To better understand the possibility of applying this technology to eradicate pathogenic viruses from foodstuffs, more targeted research is warranted.

\subsubsection{Parasites}

Due to the large size and more intricate structure of this class of pathogens, parasites represent a challenge to the effectiveness of PDT. PDT has been successfully used to treat a number of parasitic infections, but to date, the technology has not been tested on foodborne parasites.

\section{Photodynamic technology application for food safety}

The success of PDT from in vitro studies has led to interest in its practical application to a variety of foods, especially vegetables and fruits (Table 3). Inevitably, there will be discrepant results when using foods and culture medium to test PDT effects due to the complexity of foodstuffs, the diversity of microorganisms, the interactions of microorganisms with food and other contributing factors. Ideally, a technology for food disinfection should guarantee both food safety and food quality. The PDT treatment protects food quality while decontaminating the food, making it attractive as a substitute for conventional thermal treatment.

\subsection{Vegetables and fruits}

Vegetables and fruits are purchased usually fresh and ready-to-eat. In recent years, the consumption of fresh fruits and vegetables has been on the rise, and this has been accompanied by a growing incidence of foodborne pathogen outbreaks. For this reason, practical tests using PDT, for the most part, have centered on vegetables and fruits.

Paškevičiūte et al. (2009) [26, 27] and Rasiukevičiūtè et al. $(2015,2016)[72,73]$ made considerable effort to explore the application of PDT to fruits and vegetables. PDT, mediated by Na-Chlorophyll salt, was effective in ridding strawberry surfaces of inoculated bacteria, harmful yeasts and micro-fungi without loss of visual quality and nutritional value. It even improved strawberry quality by prolonging shelf life and increasing total antioxidant activity. In addition, PDT treatment also applies to other vegetables 
Table 3. PDT application in food decontamination.

\begin{tabular}{|c|c|c|c|c|c|}
\hline Food stuff & PS & Light source & Microorganisms & Reduction & Reference \\
\hline $\begin{array}{l}\text { cherry } \\
\text { tomato }\end{array}$ & \multirow{4}{*}{$\begin{array}{l}\text { Chl-derivative } \\
\left(1.5 \times 10^{-4} \mathrm{M}\right)\end{array}$} & \multirow{4}{*}{$\begin{array}{l}\text { LED }(400 \mathrm{~nm} \text {, } \\
20 \mathrm{~mW} / \mathrm{cm}^{2} \\
30 \mathrm{~min})\end{array}$} & \multirow{4}{*}{$\begin{array}{l}\text { Bacillus cereus, } \\
\text { mesophils }\end{array}$} & $\begin{array}{l}2.33 \log , \\
2.47 \log \end{array}$ & \multirow{4}{*}{ [27] } \\
\hline nectarine & & & & $\begin{array}{l}2.88 \log \\
2.02 \log \end{array}$ & \\
\hline $\begin{array}{l}\text { iceberg } \\
\text { lettuce }\end{array}$ & & & & $\begin{array}{l}1.68 \log , \\
1.96 \log \end{array}$ & \\
\hline $\begin{array}{l}\text { Chinese } \\
\text { cabbage }\end{array}$ & & & & $\begin{array}{l}1.84 \mathrm{log}, \\
1.48 \mathrm{log}\end{array}$ & \\
\hline cauliflower & \multirow{3}{*}{$\begin{array}{c}\text { hypericin } \\
\left(1.5 \times 10^{-5} \mathrm{M}\right)\end{array}$} & \multirow{3}{*}{$\begin{array}{l}\text { LED }(585 \mathrm{~nm}, \\
\left.6.9 \mathrm{~J} / \mathrm{cm}^{2}\right)\end{array}$} & \multirow{3}{*}{ Bacillus cereus } & $0.77 \log$ & \multirow{3}{*}{ [74] } \\
\hline plum & & & & $1.1 \log$ & \\
\hline apricot & & & & $1.3 \log$ & \\
\hline peppers & $\begin{array}{l}\text { curcumin bound to } \\
\text { polyvinylpyrrolidone } \\
\text { (PVP-C) } \\
(50-100 \mu \mathrm{M})\end{array}$ & $\begin{array}{l}\text { LED }(435 \mathrm{~nm}, \\
\left.6.9 \mathrm{~J} / \mathrm{cm}^{2}\right)\end{array}$ & $\begin{array}{c}\text { Staphylococcus } \\
\text { aureus }\end{array}$ & $\begin{array}{l}2.5 \log \\
(99.7 \%)\end{array}$ & [79] \\
\hline $\begin{array}{l}\text { fresh-cut } \\
\text { apple }\end{array}$ & $\begin{array}{c}\text { Curcumin } \\
(0.5-50 \mu \mathrm{mol} / \mathrm{L})\end{array}$ & $\begin{array}{c}\text { LED }(420 \mathrm{~nm}, \\
298 \mathrm{~mW} / \mathrm{cm}^{2} \\
150-510 \mathrm{~s})\end{array}$ & \multirow{4}{*}{ Escherichia coli } & $0.95 \log$ & [59] \\
\hline cucumber & \multirow{3}{*}{$\begin{array}{l}\text { SACUR-3 } \\
(10-100 \mu \mathrm{M})\end{array}$} & \multirow{3}{*}{$\begin{array}{l}\operatorname{LED}(435 \mathrm{~nm}, \\
\left.33.8 \mathrm{~J} / \mathrm{cm}^{2}\right)\end{array}$} & & \multirow{3}{*}{$\begin{array}{l}>3 \log \\
(99.9 \%)\end{array}$} & \multirow{3}{*}{ [77] } \\
\hline tomato & & & & & \\
\hline lettuce & & & & & \\
\hline \multirow{6}{*}{ liquid milk } & $\begin{array}{l}\text { methylene blue } \\
\qquad(5 \mu \mathrm{g} / \mathrm{mL})\end{array}$ & $\begin{array}{c}\text { bromine-tungsten } \\
\text { lamp } \\
\left(200 \mathrm{~mW} / \mathrm{cm}^{2}\right. \\
10 \mathrm{~min})\end{array}$ & $\begin{array}{c}\text { Listeria } \\
\text { monocytogenes }\end{array}$ & $99.999 \%$ & [86] \\
\hline & $\begin{array}{l}\text { Na-Chlorophyllin } \\
\left(10^{-5} \mathrm{~mol} / \mathrm{L}\right)\end{array}$ & $\begin{array}{c}\text { LED } \\
(400 \sim 415 \mathrm{~nm}, \\
1250 \mathrm{lux}, 10 \mathrm{~min})\end{array}$ & $\begin{array}{c}\text { Staphylococcus } \\
\text { aureus }\end{array}$ & $\begin{array}{c}0.42 \pm 0.059 \\
\log \end{array}$ & [81] \\
\hline & \multirow{4}{*}{ endogenous PS } & \multirow{4}{*}{$\begin{array}{l}\text { blue LED } \\
(413 \pm 10 \mathrm{~nm} \\
\left.<720 \mathrm{~J} / \mathrm{cm}^{2}\right)\end{array}$} & $\begin{array}{c}\text { Staphylococcus } \\
\text { aureus }\end{array}$ & \multirow{4}{*}{$\begin{array}{c}>5 \log \\
(99.999 \%)\end{array}$} & \multirow{4}{*}{ [88] } \\
\hline & & & Escherichia coli & & \\
\hline & & & $\begin{array}{l}\text { Pseudomonas } \\
\text { aeruginosa }\end{array}$ & & \\
\hline & & & $\begin{array}{l}\text { Salmonella } \\
\text { typhimurium }\end{array}$ & & \\
\hline $\begin{array}{l}\text { pasteurized } \\
\text { cheese }\end{array}$ & $\begin{array}{l}\text { watersoluble } \\
\text { curcumin salt } \\
(0.75 \mathrm{mg} / \mathrm{mL})\end{array}$ & $\begin{array}{c}\text { LED } \\
(450 \pm 10 \mathrm{~nm}, 54.9 \\
\left.\mathrm{mW} / \mathrm{cm}^{2}, 5 \mathrm{~min}\right)\end{array}$ & $\begin{array}{c}\text { Staphylococcus } \\
\text { aureus }\end{array}$ & $4.34 \log$ & {$[90]$} \\
\hline
\end{tabular}


and fruits like nectarines, cherry tomatoes, iceberg lettuce, Chinese cabbage, apricots, plumes, and cauliflower $[27,74]$.

Curcumin, a type of natural Chinese medicine, has been found to be an effective PS and has received extensive attention from food scientists over the past five years. In these investigations, all PDT treatments reduced common foodborne pathogens on fresh vegetables and fruits (cucumbers, peppers, tomatoes, spinaches, dates, fresh-cut apples and cantaloupes), and achieved the aim of shelf life extension [59, 75-79].

Using endogenous PS, blue LED-based PDT showed the same compelling anti-microbial effects. Guffey et al. (2016) [80] effectively removed E. coli and Salmonella from fresh-cut cucumbers with $405 \mathrm{~nm}$ blue LED irradiation. Besides, Kim et al. (2015, 2017) [41, 42] combined $405 \mathrm{~nm}$ blue LED with chilling temperatures and found that long irradiation inhibited or slowed bacterial growth without damage to product quality.

Besides, it is essential to provide optimal conditions for the proper function of PS. For instance, Wang et al. (2013) [81] suggested that $\mathrm{Mg}^{2+}$ of Na-Chlorophyllin in an alkaline environment may react with $\mathrm{OH}^{-}$and reduced the efficiency of the PS. Solid particles in cloudy liquid may interfere with the interaction of light and the PS. Therefore, Na-Chlorophyllin mediated PDT, in acidic and clear liquid foods, may exert greater anti-bacterial activity. These conclusions are valuable in gaining insight into the application of PDT to liquid food sterilization.

Abundant singlet oxygen quenching agents and free radical scavengers naturally exist in vegetables and fruits [82, 83]. For whole vegetables or fruits, an intact skin protects the inner content against foreign substances, and bactericidal activity generally occurs on the surfaces. For fresh-cut vegetables and fruits or juices, however, strong internal antioxidants may suppress photodynamic activity.

It is challenging to activate PSs on spherical beans and seed surfaces using flat light sources to realize the full potential of PDT. Some scientists solved this problem by improving light devices to rotate samples continuously under illumination or implement illumination at the top and bottom concurrently $[64,63,77]$. To further enhance PDT effects, PS chlorophyllin was combined with chitosan to coat wheat grains and reduced viable moulds successfully without damage to the quality [63].

\subsection{Meat products}

Studies have shown that curcumin-mediated PDT has desirable anti-bacterial effects when treating chicken meat and skin, beef and pork [32, 76]. Edible films and coatings have been popular in recent years due to their ability to prevent contamination and prolong shelf life. When serving as carriers of PSs, they can also enhance photoinactivation activity. López-Carballo et al. (2008) [84] developed antimicrobial edible films and coatings by combining gelatine with sodium magnesium chlorophyllin or sodium copper chlorophyllin, and observed a decrease of $S$. aureus and L. monocytogenes inoculated on cooked frankfurters after photosensitization.

Additionally, an increase in the anti-bacterial effect can be achieved by enhancing the delivery system. Tortik et al. (2014) [79] found that the photodynamic inactivation rate of $S$. aureus by $\mathrm{NovaSol}^{\circledR}$-curcumin $\left(\mathrm{NovaSol}^{\mathbb{B}}\right.$-C) was effective, while curcumin bound to polyvinyl pyrrolidone (PVP-C) had an unacceptable performance. A hypothesis was posed that the micelles produced by NovaSol ${ }^{\circledR}-\mathrm{C}$ protected the internal PSs before contacting the targets. For PVP-C, however, lipophilic curcumin may be more easily released by hydrophilic PVP to the hydrophobic or fatty regions of the skin. Hence, the nature of the PS and the food being analysed may affect the quantity of effective PSs that accumulate in the target. Nanotechnology, in combination with antibodies as an effective delivery system, has proved to be a promising direction to take, which will promote the development of $3^{\text {rd }}$ generation PSs.

\subsection{Aquatic products}

There has been a long history of consuming raw aquatic products, such as sashimi, molluses, and crustaceans. Unlike vegetables, fruits and meat products, report concerning the application of PDT for aquatic products is scarce. 
$\mathrm{Li}$ (2014) [48] described a reduction in bacteria on sashimi using methylene blue based-PDT. And PDT processing could extend the shelf life of oysters for 8-12 days, while a favourable odour was retained and less odour corrupting substances were produced [85]. This shows that PDT can reduce pathogen contamination and play a positive role in maintaining oyster quality, which demonstrates the utility of PDT in a variety of aquatic products.

\subsection{Dairy products}

Lin (2012) [86] exploited methylene blue to decontaminate $L$. monocytogenes in milk and observed a $99.999 \%$ population reduction. In fact, porphyrins and riboflavin are PSs that are naturally present in milk. Among them, riboflavin shows an absorption peak in the band width $400 \sim 500 \mathrm{~nm}$ [87]. By means of this property, dos Anjos et al. (2020) [88] observed a $>5 \log$ unit inactivation of all bacterial species (S. aureus, E. coli, P. aeruginosa, S. typhimurium, and M. fortuitum) within 2-h irradiation. Analysis of sugars, proteins, and lipids showed no evident degradation of milk components except for riboflavin, and this defect could be corrected by supplementation. Confusingly, the strong bactericidal effect demonstrated in the literature was partly attributed to the milk scattering of light and superimposed back scattered light. This inference was quite contrary to the "blocking effect" described in section 5.1. This emphasised the need to determine all possible interactions among PDT elements and food matrices or components. In comparison with traditional Pasteur or UHT, novel blue light-based PDT processing without thermal effects produced less nutrition loss and lower costs, in a more convenient and safer manner. Besides liquid milk, PDT provides good control over S. typhimurium in milk powder and $S$. aureus in pasteurized cheese $[89,90]$.

\subsection{Others}

The use of photodynamic technology to decontaminate food packaging materials has been widely reported [56, 60]. Eukaryotic cells are far less sensitive to blue light than are bacterial cells [88], which indicates that the technique can be popularized as an alternative sterilization method to chlorine and ultraviolet radiation in food processing environments.

\section{Conclusions and future prospects}

Numerous studies have depicted efficient photodynamic inactivation effects on a diverse range of foodborne pathogens. Most of these reports were associated with bacterial inactivation. Several species of foodborne fungi and noroviruses were examined and found to be sensitive to PDT treatment. With regard to foodborne parasites, PDT research has not yet been undertaken.

Studies clearly indicate that photodynamic inactivation performance is interconnected with the species and status of the microorganisms involved, the PSs employed, the light source, and the incubation time. Cationic PSs are more desirable than anionic or neutral PSs to inactivate gram-negative bacteria. Numerous investigations showed that higher doses of PS or light are conducive to better effects, but self-shielding phenomena also hinder photodynamic inactivation activity. Moreover, sufficient incubation time is indispensable for ALA-based PDT, but it has no significant effect on other PDT tests. Besides increasing the dose of photosensitizer (PS) and the amount of light, enhancing the interaction of microorganism membranes and PSs by chitosan, inorganic salts and photocatalysts has been proven to be an effective way to improve photodynamic inactivation performance. Although some hurdles have been encountered during biofilm inactivation due to the robustness of the biofilm layer, combining technologies to damage the EPS may be helpful.

PDT application has been carried out on vegetables, fruits, meat products, aquatic products, dairy products, food contact surfaces and packaging materials. Compared to in vitro PDT studies, this technology works well but not as efficiently. Another inescapable issue is food quality. Data described herein demonstrates that food shelf life following photodynamic disinfection is significantly extended, and no adverse changes in nutritional organoleptic profiles have been observed.

Although, PDT holds great promise for its distinct advantages [91], its application to food products is 
still in an infancy stage. There is vast research and development still needed to optimize this technology before it is routinely used within the food industry. In the future, more studies on foodborne fungi, viruses and parasites will be needed, and the range of the tested food items should be broadened. Foodstuffs with different geometries, surfaces, antioxidant compounds, microbial ecologies, and food matrices that influence microorganism growth and PDT inactivation capacity are warranted. Improvements to the biocompatibility of PSs, aiding the PSs to cross the microorganism membranes and the flexible devices will make a difference to the photosensitization capability of the technology. Edible coatings and films, flexible light and rotary shelf equipment, an effective delivery system, and nanotechnology will support further PDT progress. Additionally, the combination of PDT with other technologies should be pursued to better control foodborne pathogens with minimal detrimental impact on food quality while providing favourable economic and environmental outcomes.

\section{ACKNOWLEDGEMENTS}

The authors are grateful to the National Key Research and Development Project (2018YFG1602500) for its support. This research was also supported by the Joint Innovation Project of the Hong Kong-Guangdong Province (2016A05053031) and Fujian Provincial Collaboration Project (2020I0010).

\section{CONFLICT OF INTEREST STATEMENT}

There are no conflicts of interest.

\section{REFERENCES}

1. CDC. 2009, Multistate outbreak of Salmonella typhimurium infections linked to peanut butter, 2008-2009 (final update), https://www.cdc.gov/salmonella/2009/pean ut-butter-2008-2009.html/

2. CDC. 2012, Multistate outbreak of Listeriosis linked to whole cantaloupes from Jensen farms, Colorado (final update), https://www.cdc.gov/listeria/outbreaks/ cantaloupes-jensen-farms/index.html/
3. Lv, S., Zhang, Y., Steinmann, P. and Zhou, X. N. 2008, Emerg. Infect. Dis., 14, 161-164.

4. Mäde, D., Trübner, K., Neubert, E., Höhne, M. and Johne, R. 2013, Food Environ. Virol., 5, 162-168.

5. Zhang, X., Liu, G. X., Teng, Z., Zhu, Z. K. and Zhou, M. K. 2002, Sh. J. Prev. Med., $14,320-321$.

6. WHO. 2015, https://www.who.int/activities/ estimating-the-burden-of-foodborne-diseases/

7. The World Bank. 2018, https://www. worldbank.org/en/news/press-release/2018/ 10/23/food-borne-illnesses-cost-us-110billion-per-year-in-low-and-middle-incomecountries/

8. FDA. 2020, https://www.fda.gov/food/ outbreaks-foodborne-illness/foodbornepathogens/

9. Scallan, E., Hoekstra, R. M., Angulo, F. J., Tauxe, R. V., Widdowson, M. A., Roy, S. L., Jones, J. L. and Griffin, P. M. 2011, Emerg. Infect. Dis., 17, 7-15.

10. Li, R., Kou, X., Zhang, X. and Wang, S. 2018, Int. J. Hyperther., 34, 177-188.

11. Meireles, A., Giaouris, E. and Simões, M. 2016, Food Res. Int., 82, 71-85.

12. Sharma, S. K., Mroz, P., Dai, T., Huang, Y. Y., Denis, T. G. S. and Hamblin, M. R. 2012, Isr. J. Chem., 52, 691-705.

13. Ackroyd, R., Kelty, C., Brown, N. and Reed, M. 2001, Photochem. Photobiol., 74, 656-669.

14. Craig, R. A., McCoy, C. P., Gorman, S. P. and Jones, D. S. 2015, Curr. Opin. Microbiol., 12, 85-101.

15. Hamblin, M. R. 2016, Curr. Opin. Microbiol., 33, 67-73.

16. Cieplik, F., Deng, D., Crielaard, W., Buchalla, W., Hellwig, E., Al-Ahmad, A. and Maisch, T., 2018, Crit. Rev. Microbiol., 44, 571-589.

17. Lin, S. L., Huang, C. L., Zhu, Z. Y., Cui, J. T., Kong, L. H. and Zheng, B. D. 2017, J. Chin. Inst. Food Sci. Technol., 18, 323331.

18. Dougherty, T. J., Gomer, C. J., Henderson, B. W., Jori, G., Kessel, D., Korbelik, M., Moan, J. and Peng, Q. 1998, J. Natl. Can. Inst., 90, 889-905. 
19. Liu, H., Xue, J. P., Jiang, Z., Chen, N. S. and Huang, J. L. 2013, Chin. J. Appl. Chem., 30, 1386-1392.

20. Ding, H. Y. 2014, Photodynamic Therapy: Basic Principles and Applications. ( $1^{\text {st }}$ ed.). Beijing: Chemical Industry Press.

21. Maisch, T. 2007, Lasers Med. Sci., 22, 8391.

22. Costa, L., Faustino, M. A. F., Neves, M. G. P. M. S., Cunha, Â. and Almeida, A. 2012, Viruses, 4, 1034-1074.

23. Buchovec, I., Vaitonis, Z. and Luksiene, Z. 2009, J. Appl. Microbiol., 106, 748-754.

24. Luksiene, Z., Buchovec, I. and Paskeviciute, E. 2009, J. Appl. Microbiol., 107, 2037-2046.

25. Paskeviciute, E. and Luksiene, Z. 2009, PTEP (Serbia), 13, 181-183.

26. Paškevičiūtè, E. and Lukšienè, Ž. 2009, Sodinink. Daržinink. (Lithuania), 28, 89-97.

27. Paskeviciute, E. and Luksiene, Z. 2009, PTEP (Serbia), 13, 50-53.

28. Ren, Y. Q., Tang, S. Z., Jin, H., Wu, X. Y., Bi, S. L. and Chen, Z. Q. 2008, Food and Fermentation Industry, 34, 56-59.

29. Ren, Y. Q., Tang, S. Z., Wu, X. Y., Bi, S. L. and Chen, Z. Q. 2008, China Condiment, 33, 37-40.

30. Ren, Y. Q., Tang, S. Z., Wu, X. Y., Bi, S. L. and Chen, Z. Q. 2008, Food Res. Int., 29, 140-144.

31. Luksienè, Z. and Zukauskas, A. 2009, J. Appl. Microbiol., 107, 1415-1424.

32. Gao, J. and Matthews, K. R. 2020, Food Control, https://doi.org/10.1016/j.foodcont. 2019.106959

33. Kairyte, K., Lapinskas, S., Gudelis, V. and Luksiene, Z. 2012, J. Appl. Microbiol., 112, 1144-1151.

34. Santos, A. R., Batista, A. F. P., Gomes, A. T. P. C., Neves, M. da G. P. M. S., Faustino, M. A. F., Almeida, A., Hioka, N. and Mikcha, J. M. G. 2019, Antibiotics, 8, 211-211.

35. Silva, A. F., Dos Santos, A. R., Trevisan, D., Bonin, E., Freitas, C. F., Batista, A. F. P., Hioka, N., Simões, M. and Graton Mikcha, J. M. 2019, Photochem. Photobiol., 95, 1230-1238.
36. Almeida, A., Faustino, M. A. and Tomé, J. P. 2015, Future Med. Chem., 7, 12211224.

37. Alves, E., Faustino, M. A., Neves, M. G., Cunha, A., Tome, J. and Almeida, A. 2014, Future Med. Chem., 6, 141-164.

38. Buchovec, I., Lukseviciute, V., Marsalka, A., Reklaitis, I. and Luksiene, Z. 2016, Photochem. Photobiol. Sci., 15, 506-516.

39. Winter, S., Tortik, N., Kubin, A., Krammer, B. and Plaetzer, K. 2013, Photochem. Photobiol. Sci., 12, 17951802.

40. Aponiene, K. and Luksiene, Z. 2015, J. Photochem. Photobiol. B, 142, 257263.

41. Kim, M. J., Tang, C. H., Bang, W. S. and Yuk, H. G. 2017, Int. J. Food Microbiol., 244, 82-89.

42. Kim, M.-J., Mikš-Krajnik, M., Kumar, A., Ghate, V. and Yuk, H. G. 2015, J. Photochem. Photobiol. B, 153, 33-39.

43. Kim, M. J., Bang, W. S. and Yuk, H. G. 2017, Food Microbiol., 62, 124-132.

44. Kumar, A., Ghate, V., Kim, M. J., Zhou, W., Khoo, G. H. and Yuk, H.-G. 2015, J. Photochem. Photobiol. B, 149, 37-44.

45. Kumar, A., Ghate, V., Kim, M. J., Zhou, W., Khoo, G. H. and Yuk, H. G. 2017, Food Microbiol., 63, 12-21.

46. Poulsen, L. V. 1999, LWT-Food Sci Technol., 32, 321-326.

47. Zhu, Y., Li, C., Cui, H. and Lin, L. 2020, Trends Food Sci. Tech., 99, 142-151.

48. Li, H. A. 2014, Anti-Microbial Photodynamic Inactivation Against Listeria monocytogenes Biofilm and Listeriolysin $\mathrm{O}$ by Methylene Blue. Master's Degree Thesis, Jinan University, Guangzhou.

49. $\mathrm{Wu}$, Q. 2016, Vibrio parahaemolyticus Biofilm Formation and Inactivation with Methylene Blue Photodynamic Technology. Master's Degree Thesis, Jinan University, Guangzhou.

50. Ma, Y. 2017, Rice-isolated Bacillus cereus Biofilm Formation and Inactivation with Antimicrobial Photodynamic Therapy. Master's Degree Thesis, Jinan University, Guangzhou. 
51. Bonifácio, D., Martins, C., David, B., Lemos, C., Neves, M. G. P. S., Almeida, A., Pinto, D. C. G. A., Faustino, M. A. F. and Cunha, Â. 2018, J. Appl. Microbiol., 125, 282-294.

52. Yang, L. H. 2019, Cronobacter sakazakii Biofilm Formation and Antimicrobial Photodynamic Technology with Toluidine Blue O. Master's Degree Thesis, Jinan University, Guangzhou.

53. Pinto, R. M., Soares, F. A., Reis, S., Nunes, C. and van Dijck, P. 2020, Front. Microbiol., 11, 952-952.

54. Barr, H., MacRobert, A. J., Tralau, C. J., Boulos, P. B. and Bown, S. G. 1990, Br. J. Can., 62, 730-735.

55. Vilela, S. F. G., Junqueira, J. C., Barbosa, J. O., Majewski, M., Munin, E. and Jorge, A. O. C. 2012, Arch. Oral. Biol., 57, 704710.

56. Brovko, L. 2010, Adv. Food Nutr. Res., 61, 119-147.

57. Martinez De Pinillos Bayona, A., Mroz, P., Thunshelle, C. and Hamblin, M. R. 2017, Chem. Biol. Drug Des., 89, 192-206.

58. Li, Y., Tang, S. Z., Ren, Y. Q., Bi, S. L., Chen, Z. Q. and Luo, M. 2008, Food and Fermentation Industries, 34, 22-24.

59. Tao, R., Zhang, F., Tang, Q. J., Xu, C. S., Ni, Z. J. and Meng, X. H. 2019, Food Chem., 274, 415-421.

60. Buchovec, I., Paskeviciute, E. and Luksiene, Z. 2010, J. Photochem. Photobiol. B., 99, 9-14.

61. En-Sheng, K., Nazzal, S., Tseng, Y. H., Chen, C. P. and Tsai, T. 2012, J. Food Drug Anal., 20, 951-956.

62. Lukšienè, Ž., Danilčenko, H., Tarasevičienè, Ž., Anusevičius, Ž., Maroziene, A. and Nivinskas, H. 2007, Int. J. Food Microbio., 116, 153-158.

63. Lukseviciute, V. and Luksiene, Z. 2020, J. Photochem. Photobiol. B, 202, 111721.

64. Žudytè, B. and Lukšienè, Ž. 2019, Photochem. Photobiol. Sci., 18, 2521-2530.

65. Baltazar, L. M., Ray, A., Santos, D. A., Cisalpino, P. S., Friedman, A. J. and Nosanchuk, J. D. 2015, Front. Microbiol., 6, 202-202.
66. de Melo, W. C., Avci, P., de Oliveira, M. N., Gupta, A., Vecchio, D., Sadasivam, M., Chandran, R., Huang, Y. Y., Yin, R., Perussi, L. R., Tegos, G. P., Perussi, J. R., Dai, T. and Hamblin, M. R. 2013, Expert Rev. Anti-infect. Ther., 11, 669-693.

67. Lukšienè, Ž. 2005, Food Technol. Biotech., 43, 411-418.

68. Temba, B. A., Fletcher, M. T., Fox, G. P., Harvey, J. J. W. and Sultanbawa, Y. 2016, Food Control, 59, 708-713.

69. Randazzo, W., Aznar, R. and Sánchez, G. 2016, Food Environ. Virol., 8, 244-250.

70. Wu, J. 2015, Detection of E. coli and Norovirus in Fresh Oysters and Research on Photodynamic Non-Thermal Sterilization Technology. Master's Degree Thesis, Ocean University of China, Qingdao.

71. Wainwright, M. 2004, Photochem. Photobiol. Sci., 3, 406-411.

72. Rasiukevičiūtè, N., Valiuškaitè, A., Uselis, N., Buskienè, L., Viškelis, J. and Lukšienè, Ž. 2015, Zemdirbyste-Agriculture, 102, 411-416.

73. Rasiukevičiūtè, N., Valiuškaitè, A., Uselis, N., Buskienė, L., Viškelis, J. and Lukšienè, Ž. 2016, J. Plant Dis. Prot., 123, 125-131.

74. Aponiene, K., Paskeviciute, E., Reklaitis, I. and Luksiene, Z. 2015, J. Food. Eng., 144, 29-35.

75. Al-Asmaria, F., Mereddy, R. and Sultanbawa, Y. 2018, Food Control, 93, 305-309.

76. Corrêa, T. Q., Blanco, K. C., Garcia, É. B., Perez, S., Chianfrone, D. J., Morais, V. S. and Bagnato, V. S. 2020, Photodiagnosis Photodyn. Ther., 30, 101678.

77. Glueck, M., Schamberger, B., Eckl, P. and Plaetzer, K. 2017, Photochem. Photobiol. Sci., 16, 1784-1791.

78. Lin, Y. L., Hu, J. M., Li, S. Y., Hamzah, S. S., Jiang, H. Q., Zhou, A. R., Zeng, S. X. and Lin, S. 2019, Molecules, 24, 2374.

79. Tortik, N., Spaeth, A. and Plaetzer, K. 2014, Photochem. Photobiol. Sci., 13, 1402-1409.

80. Guffey, J. S., Payne, W. C., Motts, S. D., Towery, P., Hobson, T., Harrell, G., Meurer, L. and Lancaster, K. 2016, Food Sci. Nutr., 4, 878-887. 
81. Wang, X. Q., Liu, Z. Y., Yu, Y. S., Xu, Y. J., Wu, J. J., Wang, W. L. and Tang, D. B. 2013, Modern Food Sci. Technol., 29, 463466.

82. Oh, Y. S., Jang, E. S., Bock, J. Y., Yoon, S. H. and Jung, M. Y. 2006, J. Food Sci., 71, 260-268.

83. Pu, H. L., Liu, N. R., Yu, R. J. and Zhang, L. 2002, Acta Pharmacol. Sin., 24, 441-443.

84. López-Carballo, G., Hernández-Muñoz, P., Gavara, R. and Ocio, M. J. 2008, Int. J. Food Microbiol., 126, 65-70.

85. Liu, F., Li, Z. J., Cao, B. B., Wu, J., Wang, Y. M., Xue, Y., Xu, J., Xue, C. H. and Tang, Q. J. 2016, Food Res. Int., 87, 204-210.

86. Lin, S. L. 2012, Anti-microbial Photodynamic Technology of Methylene Blue Against Listeria monocytogenes. Master's Degree Thesis, Jinan University, Guangzhou.

87. $\mathrm{Xu}, \mathrm{W}$. and Lu, L. X. 2012, Sci. Technol. Food Industry, 33, 154-156.

88. dos Anjos, C., Sellera, F. P., de Freitas, L. M., Gargano, R. G., Telles, E. O., Freitas, R. O., Baptista, M. S., Ribeiro, M. S., Lincopan, N., Pogliani, F. C. and Sabino, C. P. 2020, J. Dairy Sci.,103, 1261-1268.

89. Deng Y. M. 2020, Formation Characteristics of Salmonella typhimurium Biofilm and the Bactericidal Effect of Photodynamic Technology. Master's Degree Thesis, Jinan University, Guangzhou.

90. dos Santos, R. F., Campos, B. S., Rego Filho, F., Moraes, J. O., Albuquerque, A., da Silva, M. C. D., dos Santos, P. V. and de Araujo, M. T. 2019, Photochem. Photobiol. Sci., 18, 2707-2716.
91. Luksiene, Z. and Brovko, L. 2013, Food Eng. Rev., 5, 185-199.

92. Deng, X., Tang, S., Wu, Q., Tian, J., Riley, W. W. and Chen, Z. 2016, J. Sci. Food Agric., 96, 1601-1608.

93. Lin, S. L., Hu, J. M., Tang, S. S., Wu, X. Y., Chen, Z. Q. and Tang, S. Z. 2012, Photochem. Photobiol., 88, 985-991.

94. Lin, S. L., Tang, S. S., Tang, S. Z., Wu, X. Y. and Chen, Z. Q. 2011, Food and Fermentation Industries, 37, 27-31.

95. Bonin, E., Dos Santos, A. R., Fiori da Silva, A., Ribeiro, L. H., Favero, M. E., Campanerut-Sá, P. A. Z., de Freitas, C. F., Caetano, W., Hioka, N. and Mikcha, J. M. G. 2018, J. Appl. Microbiol., 124, 16171628.

96. Penha, C. B., Bonin, E., da Silva, A. F., Hioka, N., Zanqueta, É. B., Nakamura, T. U., de Abreu Filho, B. A., Campanerut-Sá, P. A. Z. and Mikcha, J. M. G. 2017, LWTFood Sci. Technol., 76, 198-202.

97. Luksiene, Z., Buchovec, I. and Paskeviciute, E. 2010, J. Appl. Microbiol., 109, 15401548.

98. Tang, S. S., Tang, S. Z., Li, H. A., Wu, X. Y. and Chen, Z. Q. 2012, Food and Fermentation Industries, 38, 68-72.

99. Jia, Y. X. 2017, Cronobacter sakazakii Biofilm Formation and Inactivation with Methylene Blue Photodynamic Technology. Master's Degree Thesis, Jinan University, Guangzhou.

100. Silva, A. F., Borges, A., Freitas, C. F., Hioka, N., Graton Mikcha, J. M. and Simões, M. 2018, Molecules, 23, 2288. 